Canadian University Music Review

Revue de musique des universités canadiennes

\title{
"Exam Wars" and the Toronto Territorial Connection
}

\section{Gaynor G. Jones}

Volume 11, numéro 2, 1991

URI : https://id.erudit.org/iderudit/1014107ar

DOI : https://doi.org/10.7202/1014107ar

Aller au sommaire du numéro

Éditeur(s)

Canadian University Music Society / Société de musique des universités

canadiennes

ISSN

0710-0353 (imprimé)

2291-2436 (numérique)

Découvrir la revue

Citer cet article

Jones, G. G. (1991). "Exam Wars" and the Toronto Territorial Connection. Canadian University Music Review / Revue de musique des universités

canadiennes, 11(2), 51-67. https://doi.org/10.7202/1014107ar

(c) Canadian University Music Society / Société de musique des universités canadiennes, 1991
Ce document est protégé par la loi sur le droit d'auteur. L'utilisation des services d'Érudit (y compris la reproduction) est assujettie à sa politique d'utilisation que vous pouvez consulter en ligne.

https://apropos.erudit.org/fr/usagers/politique-dutilisation/ 


\title{
"EXAM WARS" AND THE TORONTO TERRITORIAL CONNECTION
}

\author{
Gaynor G. Jones
}

The movie Star Wars, part four of the nine-part projected saga of the same title by Charles Lucas, revived interest in science fiction when many thought it was dead. Using the title of the Star Wars saga as a parallel might seeem like intergalactic overkill for a paper focussing on a rather narrow view of two disputes about musical examination. ${ }^{1}$ Yet these battles took on a slightly bigger scope in rivalry between Toronto musical organizations and those of London, England. The "exam wars" of the title borrows from the popular lore of Star Wars rather than any extant term used in the archival papers of some of Toronto's various musical institutions, specifically, the Toronto Conservatory of Music (TCM) known since 1947 as the Royal Conservatory of Music of Toronto (RCMT), the University of Toronto (U of T), Trinity College, the Toronto College of Music - or from the local press. There is no attempt at sustaining the parallel allegory of the Empire versus the rebel cause of local musicians, although "the force" is strong, as a Darth Vader might say. Rather the analogy is to popular culture. Where Charles Lucas succeeds in the childlike appeal of his first Star Wars release of 1977 (originally called Star Wars and subsequently retitled A New Hope) is partly in his use of popular culture. There are reminiscences of The Wizard of $O z$ in the Tin Man-type figure, and so on.

Today we peruse our local newspapers to find the icons of popular culture of the early 1990's such as Madonna or Bart Simpson dominant. Hollywood takes precedence over local or national serious musical events. Even the recent separation of the RCMT from the $\mathrm{U}$ of $\mathrm{T}$, which received its final reading and

\footnotetext{
${ }^{1}$ A shorter version of this paper was delivered at the 1990 meeting of the CUMS/SMUC in Victoria. The author is undertaking a history of the Royal Conservatory of Music, the first part of which appeared as "The Fisher years: the Toronto Conservatory of Music, 1886-1913," Three Studies, CanMus Documents IV (Toronto, Institute for Canadian Music), 1989, 59-145. She gratefully acknowledges a Social Sciences and Humanities Research Council of Canada Leave Fellowship for the initial research and the help of Susan Murley and Elizabeth Wells who were undergraduate assistants in the early part of the project.
} 
approval by the Ontario Legislature on Wednesday 26 June 1991, found little resonance in print other than brief notices in Toronto newspapers. Whereas this on the one hand reflects the way in which television news coverage dominates our lives, it on the other reflects our priorities and values about music and culture in general. Little over a century ago, even a Methods controversy, concerning the sol-fa teaching of A.T. Cringan versus the American John Holt in the 1880's could arouse passionate responses from music teachers. And, in the 1890's, disputes about examination territory, whether graded musical examinations or music degrees in Toronto and in London, England, could provoke fierce public controversy on both sides of the Atlantic. It is on that territorial dispute that this paper focuses.

What was the popular culture of the 1880's and 1890's? By 1882, according to Ottawa musician Gustave Smith:

... the chasefor dollars and luxuries had corrupted the custom of spontaneous music-making among friends, and among musicians "nous avons peu d'artistes - en profession, mais nous comptons, en revanche, beaucoup de professeurs sans profession." Music now became chiefly an "accomplishment" of young ladies who played the piano and delighted their suitors with waltzes, polkas and assorted salon pieces, pretty and sentimental ... . Upright pianos and parlour organs appeared now in every middle-class home, but serious practicing was shunned, and an artistic career, like any other pursuit not aimed at the acquisition of wealth and social position, was regarded with suspicion. ${ }^{2}$

Only five years later, the TCM's first Calendar of 1887-8 stressed the importance of playing the piano:

The piano is now an accompaniment to civilization, and it has grown to be an almost indispensable article in every household where there are pretensions to culture and refinement. It is well-nigh an orchestra in itself, and is indeed the people's instrument. ${ }^{3}$

The piano manufacturing industry was one of the major industries in Toronto in the 1890's. The most important industries were agricultural machinery (the Massey Manufacturing Co.), breweries and distilleries (Gooderham and Worts); next came clothing, engineering and book publishing; piano manufacturing was

${ }^{2}$ Quoted in Arnold Walter, ed., Aspects of Music in Canada. Toronto: University of Toronto Press, 1969, 11-12.

${ }^{3}$ Ibid.,14. 
in the next group, ranking along with furniture manufacturing and meatpacking. ${ }^{4}$

The people who played the pianos were mainly young women of the wealthiest families or from the large and flourishing middle class. To be accomplished, they would have had lessons at a leading musical establishment: in 1887, say, the TCM, preferably with the leading and most expensive teacher, Mr. Fisher, its musical director. If they studied piano at the TCM and advanced as befitted a young lady, they would undoubtedly have taken theory examinations, too. Music ranked as one of the accomplishments for becoming a fine and marriageable young lady, just as long as it was not for a career but rather to make her a more acceptable parlour adornment. Invariably the most popular subjects for examinations were Piano, Harmony and General Theory, and then Voice. The majority of the candidates were women, with a few notable exceptions of male candidates such as J.D.A. Tripp, the TCM's first graduate, who received his ATCM in piano in 1889.

The TCM affiliated with Trinity College in November 1888. It pursued a similar affiliation, which did not materialize until 1896 , with the U of T, i.e. University College. The Toronto College of Music, founded after the TCM, managed to affiliate with the $\mathrm{U}$ of $\mathrm{T}$ sooner, in 1890 . The first graduates of Trinity who were TCM students, thus receiving exemptions from the first two sets of examinations, were all female for the first three years from $1892 \mathrm{on}$. Male graduates also appeared from 1895 on. The predecessor to all these was Emma Stanton Mellish who, in 1886, had been the first woman to receive her Mus. Bac. from Trinity. Other women before her were allowed to sit the examinations and receive a certificate but were not awarded a degree.

Now there was always local scrapping, carried on in a gentlemanly fashion, between leaders of rival musical institutions in Toronto such as the TCM's Edward Fisher, a wily businessman with a smooth and silver tongue who might well have had a career in politics if not in music, and F.H. Torrington who headed the Toronto College of Music, a colourful and outspoken personage always with a veneer of charm. The following discussion necessarily excludes other important musical institutions and restricts itself to the main protagonists in the "exam wars". The local examination stakes were relatively small compared with the probable gains from branching out to much larger territory in a network of local examinations, all made possible by people and railways across the country.

The earlier of the two controversial battles concerns the University of Trinity

${ }^{4}$ J.M.S. Careless, Toronto to 1918: an Illustrated History. Toronto: J. Lorimar and Co., 1984, 112. 
College, Toronto, or Trinity College as it is known today. It started when Trinity allowed publication of its curriculum and examination papers in the American journal, The Key Note. It was as a result of their subsequent publication in the London Musical Standard that the English furore started. The TCM, which had been affiliated with Trinity since 1888 , shared some of the adverse publicity when a group of 35 of the most prominent English musicians protested against Trinity's granting in absentia degrees in England. These musicians included Sir John Stainer, Sir Hubert H. Parry, Sir Charles Villiers Stanford, Sir Arthur Sullivan and Sir George Grove. Representing British Universities and Colleges of Music, among them Oxford and Cambridge, and also representing the Associated Board of the Royal Academy of Music and the Royal College of Music for Local Examinations, they signed a protest called the "Memorials", presented on 24 February 1890 to the Right Honourable Lord Knutsford, H.M. Secretary of State for the Colonies. They objected to the issuing of music degrees by Trinity College in England, where all the examinations took place and where all three examiners were English church organists and non-residents of Canada. The examiners included Edwin Matthew Lott, who was also an examiner for the TCM. Toronto retaliated to clear up the English "misapprehension" about the Trinity degrees.

This year some 50 Canadian candidates are presenting themselves for ... Mus.Bac. in Toronto. The TCM, which has entered within the last two years over 1,000 pupils, is affiliated to this University, and a complete course of Musical Instruction alike theoretical and practical is given in this affiliated College. $^{5}$

Although Trinity objected to the assertions that its degrees had been "lowering the standard of music education," and had insisted, on the contrary, that they had served "to greatly stimulate musical study," 6 this position was debatable. There had been some controversy in Toronto about the quality of the Trinity degrees. ${ }^{7}$ Trinity was not alone in offering external degrees in Britain and, by its royal charter, had every right to do so. After its Provost C.W.E. Body was unable to resolve the controversy by a trip to England, Trinity decided early in 1891 to discontinue its external examinations in London and also in New York, where they had been held simultaneously. In 1904, when Trinity became a federated college of the $\mathrm{U}$ of $\mathrm{T}$, it relinquished its degree-granting powers in all faculties

\footnotetext{
${ }^{5}$ See item one in the Memorials Presented to Lord Knutsford, H.M. Secretary of State for the Colonies, with Appendices etc. London: William Brown and Co., 5.

6 Ibid., 7.

7 G. Jones, "The Fisher years: the Toronto Conservatory of Music, 1886-1913," Three Studies, CanMus Documents IV (Toronto, Institute for Canadian Music), 1989, 105-6.
} 
except Divinity. Thus its Music Faculty ended after having granted 161 B.Mus. degrees - including one honorary and 34 D.Mus. degrees - including six honorary. ${ }^{8}$

An interesting aside is that in 1885 , the year that the University of Trinity College, Toronto, had first held its B.Mus. degree examinations simultaneously in London and Toronto, it had turned down an application for affiliation from London's Trinity College of Music, which from 1881 had set up external examination centres in S. Africa, India, Ceylon and Australia. The English College later offered theory exams in Canada in 1887 but did not start sending practical examiners to Canada until 1908, a practice which continues today. Humfrey Anger pointed out the irony of London's Trinity College intention of introducing practical musical examinations in Canada in a letter written in August 1898 from England. That the Canadian degree examination controversy was not trivial is indicated by Anger's second paragraph:

When the University of Trinity College, Toronto, some 10 or 12 years since, commenced to hold its examinations of music in this country, there was considerable excitement; the Universities banded together to rid them of the intruder. A strong and representative committee was formed; the Colonial Secretary received the deputation, and Parliament was invoked; finally, ..., the examinations ceased to be held. I say finally, though not until last year (1897) did the completed examinations of the Canadian University really terminate in this country. ${ }^{9}$

Clearly, then, the British won the Trinity versus London war. The tone of the British Universities and Colleges of Music at the intrusion of a Toronto institution into London, England, for the purpose of offering external degrees was scornful but much more restrained than that of the participants in the subsequent "exam wars" later in the decade. That was when some Toronto musicians, gradually joined by others, dared to tangle with the highly organized mechanism of the Associated Board of the Royal Academy and Royal College of Music of London. It is appropriate, then, to skip forward from 1891 to the "exam wars" which raged more fiercely and bitterly in 1898 and 1899 . Verbal exchanges between Canada and England in these later "exam wars" voiced

8 Henri Pilon, "University of Trinity College," Encyclopedia of Music in Canada, Helmut Kallmann, Gilles Potvin and Kenneth Winters, eds. Toronto: University of Toronto Press, 1981.

${ }^{9}$ Saturday Night, XI No.43 (10 September 1898), 10. Anger was right about the last English examinations taking place in 1897. Those candidates who registered before 1 February 1891 were given the chance to complete their degrees up until 1897. See the Corporation Minute Book, 13 June 1894, Trinity College Archives. 
similar outrage but were far less decorous and even descended to personal mudslinging.

These "exam wars" had fairly innocuous beginnings, it seems, with Percival J. Illsley's letter of 20 June 1893 to the Hon. Secretary of the Associated Board in London. Illsley's letter expressed the "strong desire in Montreal for practical examinations from some recognized Institutions ..." and wanted to induce the Royal Academy of Music to open an examination centre in Montreal. At that time, Illsley wrote, the London College of Music, with its centres in Ottawa and Montreal, was "the only English institution holding examinations in Canada."10 By the time Illsley's successor, Samuel Aitken, tried to follow up on Illsley's suggestion for Associated Board examinations in Canada over three years later, he was too late. For Illsley had already established his own Canadian examination system, having founded, with J. Edgar Birch and Horace Reyner, the Dominion College of Music in 1894 (incorporated in 1895) with the express purpose of administering examinations, both practical and theoretical. This Illsley explained to Aitken in a letter of 11 January 1897. Meanwhile,F.H. Torrington, always one to join the fray whether or not invited, wrote to Aitken on 28 December 1896 that he had pushed for Associated Board examinations in Canada for years. Soon, in a letter of 13 February 1897, Torrington was proposing a monopoly for the Toronto College of Music: (i) that this institution was to have the exclusive representation for the whole Dominion, or, if not, at least for Ontario, Manitoba, British Columbia and Quebec; (ii) that he be the associate examiner for the practical examinations; (iii) that the Associated Board share one half the costs of sending an examiner; (iv) that this be a five-year agreement. As Aitken responded in his letter of 5 April 1897, the Associated Board was not in the habit of appointing exclusive representatives, always sent its own examiners, and could not commit itself to a five-year term. The Associated Board would examine Torrington's candidates if he could guarantee the expenses. Aitken claimed never to have had a reply from Torrington. It was Torrington, however, who further fuelled the spark of English interest in Canadian examination territory.

So the Associated Board proceeded. In August it approached the U of T's President Loudon to enlist his help in supporting the Board's proposed Canadian examinations in November 1898. The Board planned its regular graded practical exams, plus a teacher's examination in piano, violin and singing leading to the diploma CTAB (Certified Teacher of the Associated Board). The Globe's interview of 22 September 1898 with the Associated Board's local representative, Lieut. Col. Davidson, really ignited the controversy in the press.

${ }^{10}$ The Case of the Associated Board [Samuel Aitken, compiler]: 1899, 11. 
A writer in Saturday Night, in October 1898, remarked:

Lieut. Col. Davidson's sudden conversion to the cause of music and his burning desire to help matters along in this line, are a sublime spectacle of zeal and devotion to a good cause. [....] His statements possess the charm of novelty in a marked degree, one of which being to the effect that opposition to the English examinations may be taken as "proof of their necessity." The same basis of reasoning carried into other departments of our life, the Health Department, for example, would indicate the desirability of a small-pox visitation because of the efforts which are made from time to time to effectually deal with this problem. ${ }^{11}$

May Hamilton described the 26 September mass meeting of Ontario musicians at the YWCA on Elm Street, Toronto. The evening's orator was S.T. Church, Toronto, who described the Associated Board's "good and noble purpose" before continuing:

...the institution has apparently degenerated from the standpoint of musical advancement into one of the most commercial musical enterprises that has appeared on the horizon of the musical world. With a keen eye to the probabilities of success in the colonies its operations were extended into Australia, with the prospect after the first year that the ensuing year would net the board at least $\$ 15,000$. [...] Encouraged by commercial success the scheme of exploitation has been extended into Canada. It has been introduced without solicitation on the part of the profession as a body and without recognizing the rights of the resident musical institutions and universities, through which has been established a standard of musical examinations fully meeting the requirements of our people, and thereby rendering the introduction of foreign musical examinations unnecessary in this country. [....]

It is the duty and privilege of every Canadian interested in the educational advancement of our country to resent with telling effect the grasping tendencies of this modern octopus in its endeavour to draw within its tentacles the body musical of Canada, sapping, vampire-like, the commercial blood from its veins to the sacrifice of its musical bone and sinew.

It is sincerely to be hoped that this unsolicited and disagreeable disturbance of the Canadian musical atmosphere may result in even a higher state of

11 Saturday Night, XI No. 46 (1 October 1898), 10. This commentary appeared in the music column signed "MODERATO," which was the pseudonym of A.S. Vogt, who was Saturday Night's music critic at the time. 
professional unity, a oneness of purpose and aim, and a further advancement into the mysterious realm of our divine art in this, the brightest gem in Britain's colonial galaxy. ${ }^{12}$

The meeting, which resolved to "enter a protest against the uncalled-for introduction of the said examinations in Canada," had some advantages for its participants. For instance, F.H. Torrington laughingly asserted that if Aitken "by his actions welded Canadian musicians into a harmonious group, he would be their benefactor." May Hamilton described the proceedings as "absolutely respectful," yet she reported Edward Fisher as saying that there seemed to be "a screw loose" in those institutions, especially for proposing the teachers' examination, which was "the most disgraceful." Furthermore Augustus Vogt quoted a satire from London Truth:

You don't become a man of letters

By putting the alphabet after your name;

One suffix alone the fact expresses

And that is an "a" and a couple of "s's."

There were, however, real concerns about the standards of the Board's proposed CTAB examinations. Yet however real these concerns, it is difficult to say how justified they were. But the whole issue became a rallying cry for Canada versus England. This was pointed out in J. Humfrey Anger's letter which reminded Canadians of how the English had opposed Trinity College's examinations:

To every Englishman who knows the meaning of fair play it will be clear that the old cry of "Canada for the Canadians" is only right and just: we are old, stable and experienced enough to do our own business. As Sir John Stainer said in his memorable speech at the Inauguration of The Union of Graduates in Music, "Canadian dollars are good enough coins, quite as valuable as our money, but they are made for and must be kept in Canada, not exported over here." Per contra, we say just the same of English money and English examiners. ${ }^{13}$

Nor were the insults generated from just this side of the Atlantic. Aitken, in "A Page of Abuse", countered Fisher's taunts of a "screw loose" with the Associated Board and its "disgraceful" examination, with the following testimonial

12 This and the following quotations are drawn from May Hamilton's "Music in Canada", The Musical Courier, XXXVII No. 14 (5 October 1898), 8-9. Her references to Voght and Auger have been changed to Vogt and Anger.

${ }^{13}$ Saturday Night, XINo.43 (10September 1898), 10. The first four lines of this quotation were also cited in Hamilton's report. 
of Fisher's ability:

A brilliant pupil of his told me a few days ago that the Doctor could not write a line of counterpoint to save his life. The Doctor may easily disprove this by taking our next examination. ${ }^{14}$

Aitken also quoted some of the more colourful comments of A.S. Vogt, who, Aitken said:

Calls to his assistance the zoological kingdom. The ass - the mule - assist him in his kind remarks about the Board. He talks of the examinations as "Trumpery - Oldfashioned - A scramble for lucre - A traffic in certificates - Certificate peddling - Bargains in degrees - Absurd buncombe Twaddle - Huckstering concerns - Flimsy tests - Absurd schemes Sharing the swag - Ludicrous campaign - Bumptious declaration - Coarse invective - Untruthful methods - Asinine tactics - Mulish obstinancy [sic] - Bolstering up a farce," etc., etc.

He mixes up Christmas plum pudding and its attendant indigestion and purchases of C.P.R. shares (what these have got to do with musical examinations I fail to see) with personal abuse of a highly-respected and able brother musician, the latchet of whose shoes he is not worthy to unloose. There is no argument in this sort of thing. Neither would there be any were it said that had the Conservatory "sweated" Mr. Vogt to the tune of $50 \%$ of his fees, he might not now be putting up a new palatial residence in' Bloor St. ${ }^{15}$

Further interchanges followed. May Hamilton reported, after the 15 October meeting of musicians at the Queen's Hotel in Toronto, that the protest was approaching "colossal proportions." 16 Opposition to the examinations was not uniform, however. J.E.P. Aldous, who founded the Hamilton School of Music and directed it during 1889-1908, and whose name appeared in the membership list of the Associated Musicians of Ontario, considered that the grounds for opposing the Associated Board were mostly "fallacious" because a pass was fifty per cent in Toronto, two-thirds in England; the Toronto examiners charged $\$ 7$ without crossing the Atlantic whereas the Associated Board charged $\$ 7.50$ for its senior examination. ${ }^{17}$

14 The Case of the Associated Board, 14.

15 Ibid., 14.

16 The Musical Courier, XXXVII No. 17 (26 October 1898), 5.

17 The Case of the Associated Board, 16. 
A delegation from the TCM's Board had tried to meet Lord Aberdeen who was too busy before leaving Canada. The TCM's Board suggested in December having the Universities of Toronto and of Trinity College act together on this matter. ${ }^{18}$ A committee submitted a Protest against the Introduction into Canada of Examinations by Musical Examining Bodies Outside of the Dominion to the University Senate on 17 February 1899 . The motion to adopt the Protest lost by one vote (thirteen votes to fourteen). ${ }^{19}$ Major L.G. Drummond, Secretary to the Governor-General of Canada, wrote on 6 March 1899 from Government House to S.T. Church, who represented the protesters, regretting that his Excellency could not endorse the views expressed in the Protests:

The reputation of the Associated Board of the Royal Academy of Music and Royal College of Music stands so high that he can hardly think that examinations conducted under its supervision could tend either to lower the standard of Canadian institutions, or to create antagonistic factions; indeed they would appear to him likely to produce entirely opposite results. The Board now sends examiners to Australia and to South Africa, and the diplomas it grants are practically the only ones that carry any value in the eyes of the musical world. ${ }^{20}$

Although he sympathized with the protestors, Lord Aberdeen found that the Associated Board's examinations would add to the success of Canadian institutions rather than proving detrimental to them.

Meanwhile Aitken was busy with public insults. In his letter to The Globe of 28 February 1899 , he asserted "that, with a few honorable exceptions, there is no teaching in Canada worthy of the name." The Board's purpose, he maintained, was to encourage good and expose bad teaching.

When I see that students can get letters to their names without being required to play a study or even a scale in thirds or sixths - when they can substitute pieces of a lower grade for those of the highest examinations (on the principle, I suppose, that two commoners make one lord and two lords make one duke) - and when they can be passed at the low grade of 50 out of 100 marks; then I can believe anything.

His patronizing tone aside, he did have a point about the marking scheme. The Associated Board required a passing grade of 66 out of 99 for most of its

18 Minutes of the Board of Directors of the TCM, 9 December 1898.

19 Minutes of the Senate of the U of T, U of T Archives, A70-0005.

20 The Case of the Associated Board, 20. 
examinations and 75 per cent for the teachers' examination. Yet it is not possible to ascertain exactly how demanding a pass was for a comparable examination of either institution. Indeed it is extremely difficult to tell what the comparative standards were like at the time. Many of the TCM's teachers had been trained at leading conservatories in Europe, England and the United States. It is unlikely that a man like the TCM's musical director Edward Fisher, educated as he was at the New England Conservatory in Boston and in Berlin, or that the Toronto College of Music's director Torrington, who was trained in England, would deliberately set low standards to get more clients. Also the extant records, such as the minute-books of the early years of the TCM, show that Fisher was quite discriminating in his selection of teachers and examiners.

Aitken claimed that the Ontario musicians feared diminished revenue and revelation of their bad teaching. His assessment of the Protest document was that it was either a "piece of crass stupidity or ... a piece of wilful wickedness." Yet when Aitken asserted that no one in Canada was worthy of the name teacher, he was pulling at the very foundations of what these musicians, many of whom were British-trained, had built. Aitken insisted that the Associated Board was not a money-making concern and that in the Royal Academy and Royal College of Music, the pupils' fees did not cover the cost of their musical education. He contrasted that with the two Toronto institutions, alleging that the director of one [Fisher] owned over half the stock, an exaggeration which he later retracted. Fisher held $\$ 6,000$ of $\$ 32,500$ of stock. Aitken had heard, too, that the principal of the other [Torrington] was trying to sell his college to an English syndicate at 10,000 pounds sterling. On the contrary, he maintained, every penny of the Associated Board's profit on the examinations would be used for scholarships.

Other small verbal battles proliferated. Aitken, inflamed by a letter by Church, continued to criticize the local musical institutions' concerns about money, as if the Associated Board had no financial motives. Aitken had met with Fisher and Vogt in Toronto. He had offered to divide the fees, work and expenses of examinations with them but objected to Vogt's "coarse and unmannerly expression about 'sharing the swag"'. Fisher had asked what the TCM would get in exchange: the TCM acquired its revenue from fees for lessons and examinations and had paid a six per cent dividend to its shareholders the previous year. Aitken offered to give the TCM a monopoly over the Associated Board examinations. The most serious allegation was that the Associated Board examinations would lower musical standards in Canada. No one received an Associated Board certificate without meeting the standards. Montreal had not subjected him to "the vulgar abuse which has so freely been showered on us in Toronto." Aitken hoped that Associated Board members would not be considered 
"foreigners" in Canada and their examinations "foreign invasions". The use of such expressions had lost for the Toronto cause the support of one of its universities, Aitken maintained. Yet he found it "most amusing to think that good, honest English and Scotch names should be described as foreigners by a gentleman who spells his name V-O-G-T." Aitken also queried the impartiality of examiners Vogt, Fisher and Harrison at the TCM, alleged that Fisher controlled his external examiner, W.H. Sherwood, and overruled his vocal examiner, Signor Agramonte, and queried Anger's impartiality as a theory examiner. He even claimed that Torrington overruled W.E. Fairclough's examination marks at the Toronto College of Music, ${ }^{21}$ which Fairclough later denied.

Vogt might well have ignored allegations about lack of impartiality on examinations as being without foundation and left them to the board of Directors of the TCM to refute in its own letter to The Toronto World. Yet he could not overlook the allusion to the origin of his name in his reply:

His special grievance against me in connection with the Associated Board's venture in Canada seems to be that although a native Canadian and a loyal subject of our beloved Queen, I spell my name in a manner which offends him. This important matter of detail will not, I trust, disturb the equilibrium of our disgruntled critic too acutely, inasmuch as a much less humble personage than a mere "Colonial" musician, namely the President of the Associated Board - the Prince of Wales himself - is the owner of a family name which is equally suggestive of such dainties as sauerkraut, limburger and lager. However, on this side of the Atlantic we love and respect his Royal Highness none the less because of this fact. ${ }^{22}$

Vogt attributed Aitken's bad temper to various causes: the Associated Board's wrangle with the Incorporated Society of Musicians of England; the criticism by Dr. Vincent (of the Incorporated Society) of the Board's CTAB examination, for which candidates were "not expected to give attention to faults of style or lack of expression," according to the Board's syllabus for this $\$ 25$ title; lastly Aitken had "miserably failed to intimidate Canadians into meek subjection to the ludicrous 'mission' whose advance agent he is." Aitken responded in a letter dated 12 March 1899. He had not intended "to take part in any further newspaper warfare," and it is a pity that he succumbed to the temptation. Aitken's letter ended with:

21 The Toronto World, 10 March 1899.

22 Ibid., 12 March 1899. 
I call upon all who have felt the burden and tyranny by which their art is enchained to separate themselves from its present bondage and to make a bold stand for liberty of teaching and examination, meaning, as it must, the advancement and emancipation of music. ${ }^{23}$

Unfortunately, Aitken descended to allusions of slavery and colonial superiority in his remarks. If the Canadians were so ill-mannered, why was an English gentleman in his position not only questioning the awarding of marks and certificates at the TCM and the Toronto College of Music, but also casting aspersions at the quality of teaching music in Canada? One can only assume that much of Aitken's criticism was based on local gossip. For someone professing so much virtue, Aitken showed questionable ethics in trying, unsuccessfully, to acquire shares of TCM stock. The TCM's Board disallowed the stock transfer because Aitken's letters published in the press "revealed him, it was believed, as an open and avowed enemy of the institution."24

The transatlantic conflict about the Associated Board examinations was due not so much because of the examinations themselves but because of the high-handed manner in which Aitken and other Associated Board members described the Canadian musical scene and its teachers. To treat people like Fisher, Torrington and Anger as colonial upstarts was hardly diplomatic. Fisher was Americanborn; Torrington and Anger were British immigrants; Vogt, who received the most abuse, was Canadian-born to German and Swiss parents in Washington, near Kitchener-Waterloo. All of them had committed their energy and expertise to Canada, which was something that Aitken could not understand. Canadians were not asserting that their examination systems were perfect. There were certain modifications to the marking scheme of TCM examinations which came as a direct result of this controversy, whether or not the TCM admitted it. Fisher's proposal requiring 60 marks for a pass, 70 for honours and 80 for first-class honours and the addition of a new Primary examination in all departments except voice was approved at a TCM Board meeting of 23 March 1900.

There is no doubt that business interests motivated the Associated Board. This was hotly denied by Aitken. The more he maintained that the Board did not intend to make a profit, the more insincere it seemed. Would the Associated Board really send its representatives across the Atlantic to examine at a loss? The Canadians were concerned about fees. If the Associated Board were to cultivate the Canadian territory successfully, the probable loss of revenue would be great.

23 Ibid., 13 March 1899.

${ }^{24}$ Minutes of the Board of Directors of the TCM, 5 July 1899. 
This competition for territory was one of the reasons that the TCM established its own local-centre examinations in 1898. It is from these "exam wars" between Canada and England that we have inherited the exaggerated emphasis on practical examinations which remains with us today.

The Associated Musicians of Ontario was formed in 1899 to prevent the Associated Board from introducing the English examinations into Canada. It planned to institute its own "practical examinations in music under the auspices of the $U$ of $T$, in co-operation with a council representing the musicians of Ontario."25 Instead of rival schools bickering among themselves, they were uniting for a cause. On 15 January 1900, the Associated Musicians of Ontario wrote to the Senate of the $U$ of $T$ proposing practical examinations in music in local centres in Hamilton, London, Ottawa and Toronto. The $U$ of $T$ would administer the examinations, receive the fees and absorb the expenses.

The correspondence which ensued was not as acrimonious as previous interchanges about the Associated Board Examinations. On the contrary, it was in the restrained style which befits institutions of higher learning. In effect, it was a series of delaying tactics on the part of the Associated Board, which tried to delay the negotiations for which the Ontario musicians were pushing so hard. The persistence of the Associated Board's interference with U of T matters is ironic when contrasted with the outrage of British University and College musicians who effectively terminated the examinations of Toronto's Trinity College in London.

Too much procrastination from the $\mathrm{U}$ of $\mathrm{T}$, not an unusual ploy for that institution, resulted in the $\mathrm{U}$ of $\mathrm{T}$ setting up its own examinations, establishing its initial local centres in 1901. By January of the following year, the TCM Board was already querying whether there was any need for the $U$ of $T$ to be engaged in practical examinations in instrumental and vocal music since this was duplicating the work of the TCM, which had been teaching and examining for fifteen years (the last three years of which the examinations had been open to the public). ${ }^{26}$ By now, the TCM local examinations established in 1898 had grown, centres having been established in thirty cities and towns of Ontario and

25 Preliminary meeting, 23 February 1899. See also the pamphlet An Account of the Canadian Protest against the Introduction into Canada of Musical Examinations by Outside Musical Examining Bodies, Toronto, March 1899, for the Canadian Protesting Committee's point of view. ${ }^{26}$ Letter of 10 January 1902 from the Board of the TCM to James Brebner, Registrar of the U of T. This five-page typescript is tipped in to the Minutes of the Board of Directors of the TCM, between 290 and 292. 
Manitoba. The passionate intensity of the Associated Musicians of Ontario's cause was not sustained; members apparently lost interest due to all the delays and only seven or eight members had appeared at one of its meetings, according to the letter of 10 January, 1902, from the Board of the TCM to U of T Registrar James Brebner. Furthermore, the letter questioned whether the $U$ of $T$ should be in the business of giving practical examinations at all. Things were not to run smoothly for the U of T's practical examinations over the next couple of years.

During the period under scrutiny, the Associated Board decided that it would be best to continue its examinations and let public opinion decide. Thus the storm died down. The Associated Board introduced its examinations at McGill University in 1902 until McGill set up its own examination system in 1909. After that, the Associated Board established its own centres and gave its examinations in Canada. The war with the English examinations was not won until 1953, when the Associated Board withdrew its examinations from Canada. The acrimonious interchange between representatives of the Associated Board, which saw in the Canada of the 1890's a virgin territory ready for the taking, and the musicians of Ontario had some positive side-effects. It resulted in a unique circumstance in which the directors of competing musical institutions banded together against the "foreign invasions" of the Associated Board. These men included Fisher and Torrington, C.L.M. Harris, the founder of the Hamilton Conservatory of Music, and W.O. Forsyth, the director of the Metropolitan School of Music. Secondly, it may have prompted Fisher to rethink the examination standards of the TCM. Thirdly, and most important, it placed an undue emphasis on practical examinations in this country. Yet this last has had positive side-effects in that the TCM still receives most of its revenue from examinations rather than from teaching. It is the success of its examination system which has helped the TCM's survival when many of its competitors were taken over by other institutions or closed.

Neither Fisher for the TCM nor Aitken for the Associated Board was in the business of music exams for altruistic ends. Since S.T. Church had in a rousing speech in 1898 talked of "a higher state of professional unity" for musicians and "a further advancement into the mysterious realm of our divine art in this, the brightest gem in Britain's colonial galaxy", perhaps recalling Star Wars is not too far afield. The good and bad were not totally clear-cut in either examination camp. It calls to mind Luke Skywalker's struggle with the dark side within himself as Lucas' hero grows through adolescence in The Empire Strikes Back. Lucas retitled part four of Star Wars from Star Wars to A New Hope. With the TCM's recent separation from the U of $T$ and its examination commission, which 
undertook its study in January 1990 and completed its findings in May 1991, ${ }^{27}$ there is new hope for the future. The fear of foreign competition still lurks, however, as during the fall of 1990 the Associated Board started stepping up its marketing campaign in $\mathbf{N}$. America.

There is embedded in the popular lore of Star Wars much Christian imagery in the depiction of the struggle between the good and the bad forces, or the good and bad forces which co-exist in each side. Contrast, then, the tone of Samuel Aitken's summation on the second exam war, "A Parable and a Paraphrase," which may speak for itself in conclusion:

Now it came to pass in a large country called Canada that certain men, Professors of Music, invited a fully equipped and honorable body called the Associated Board, to examine their disciples and students, and to see whether they were receiving a goodly training, and were sound in the musical faith.

And sometime afterwards these Professors fearing the loss of fees, and fearing also that their teaching and work should be made known, did alter their minds.

And with one consent they all began to make excuses, and they tried to let and hinder the work of the Hon. Board which they had invited to that country. And there arose no small stir about that way in a city called Toronto.

For certain men (the aforesaid Professors) which made and dispensed diplomas and certificates to their disciples, brought no small gain unto the craftsmen;

Whom they called together with workmen of like occupation (as many as would come) and said Sirs, ye know that by this craft we have our wealth.

Moreover, ye see and hear that not alone in Canada but almost throughout all the world, this Board hath persuaded and turned away much people from bad to good teaching, saying that they be no examinations (which are played with hands) without thirds and sixths and studies, and which get letters at marks two score and ten per cent.

So that not only this our craft is in danger to be set at nought, but also the great Temples of Music should be despised and their dividends destroyed.

${ }^{27}$ Norman E. Burgess, Warren Mould, G. Campbell Trowsdale, "The Report of the Royal Conservatory of Music Commission on the National Examinations". Toronto: May, 1991. 
And when they heard these sayings they were full of wrath and cried out saying "Canada for Canadians," and they rushed with one consent to the common hall.

And the whole city was filled with confusion, and some cried one thing and some another; for the assembly was confused; and the more part knew not wherefore they were come together.

And when the Hon. Board would have made its defence to the people they cried and clamored for the space of six months: "Great are the Temples of Toronto."

And when the people were appeased — one said, "ye men of Toronto - what man is there that knoweth not now that the city of Toronto is a worshipper of the great Goddess of Music - and of the College and Conservatory the temples which fell down from Jupiter.

"Seeing then that these things cannot be spoken against, ye ought to be quiet and do nothing rashly.

"For this Hon. Board which ye have brough[t] thither, are neither robbers of CHURCHES nor yet blasphemers of your Goddess.

"Wherefore if the professors and craftsmen which are with them have a matter of music against any man, the law of the art is open, and there are the prophets and masters, let them be enquired of.

"But if ye enquire anything concerning commercial and money matters and dividends it is a shame to speak of those things before the great Goddess of this art.

"For ye are in danger to be called in question throughout the world for this uproar, there being no cause whereby ye may give an account of this concourse."

So the assembly was dismissed. Every man returned to his vine and fig tree, and the Hon. Board pursued its good work and was had in reverence of all men. ${ }^{28}$

${ }^{28}$ The Case of the Associated Board, 27. 